\title{
PhET Simulation Effectiveness as Laboratory Practices Learning Media to Improve Students' Concept Understanding
}

\author{
Nailil Inayah"1, Masruroh² \\ ${ }^{1}$ Natural Science Education, Faculty of Science Education and Teaching Trainer, Islamic \\ State University of Sunan Ampel Surabaya. Jl. Ahmad Yani No.117, Jemur Wonosari, \\ Wonocolo, Surabaya, East Java, Indonesia. Postal Code: 60237. \\ ${ }^{2}$ Informatics, Faculty of Engineering, Universitas Islam Lamongan, Jl. Veteran No.53A, \\ Lamongan , East Java, Indonesia. Postal Code: 62211. \\ *Corresponding Author e-mail: nailil.inayah@uinsby.ac.id
}

Received: September 2020; Revised: July 2021; Published: December 2021

\begin{abstract}
PhET Simulation could be an alternative learning media for subject which is need laboratory practices that could not be adapted well in distance learning during pandemic of Covid-19. This study attempts to describe the effectiveness of PhET Simulation as learning media for laboratory practices during pandemic. This research is pre experimental research using pre-test post-test design with 30 students as sample that was taken using saturated sampling technique. The effectiveness of PhET simulation is seen from student's concept understanding, and student's response. The instruments used in this study was students' understanding concept test sheet and responses questionnaire. The effectiveness analysis of PhET Simulation that is integrated in distance learning was done by analyzing students' pretest and post-test scores by using paired-sample t-test, ngain score average, and students' responses. The results showed that there is significant increase of students' concept understanding at $\alpha=5 \%$, the average $\mathrm{N}$-gain of students concept understanding was 0.63 (medium), and also the implementation of PhET simulation achieved very positive responses. Overall, it can be concluded that the PhET simulation is effective as a learning media for laboratory practices during pandemic to improve students' concept understanding.
\end{abstract}

Key Word: Phet, media, lab work, learning, pandemicc

How to Cite: Inayah, N., \& Masruroh, M. (2021). PhET Simulation Effectiveness as Laboratory Practices Learning Media to Improve Students' Concept Understanding. Prisma Sains : Jurnal Pengkajian Ilmu dan Pembelajaran Matematika dan IPA IKIP Mataram, 9(2), 152-162. doi:https://doi.org/10.33394/j-ps.v9i2.2923

\section{INTRODUCTION}

The emmerge of Corona Virus Disease-2019 (Covid-19) pandemic triggers various change in our life, no exception in education sector. Based on government regulation no 21 year 2020 about social restrictions large scale in order to accelerate the handling of Covid-19, the Minist of Education and Culture number 33 year 2019 about safe education unit of the administration of the disaster, and the Health Minister number 9 year 2020 social restrictions on guidelines for large scale in order to accelerate the handling of Covid-19, learning at the school advised to be enforced from home using online learning. Education which was originally dominated by the system of learning face to face directly, now shifted being a system of long distance learning or learning with online system. This matter is intended to maintain the security of the community from the danger threat of Covid-19. 
The shift of this learning system is certainly demand a readiness from various part such as the education institution, lecturers, students and also their parents who assist their learning from home. Alternative learning activities suggested in the pandemic is online learning using Learning Management System (LMS), either it is a developed system for educational institutions itself or already available on the internet like Google Classroom and meeting, Schoology, Edmodo, Zoom, Kahoot, Youtube, Quizzez, Whatsapp group and other media platform. For some, online learning material can be adapted well, but for some other material particularly those who need lab work in the new concept understanding would require something more than just a tutorial learning through existing LMS. Preference of students against various online media is based on need and capacity of each media, suppose from the affordability of the costs/ quota, the accessibility and stability of connection although in limited signal. In addition, based on the research, some method of online learning by lecturers is not so interactive that causes students boredom and lack of concept comprehension in certain learning material (Farida et al., 2020).

According to survey in Biology Program of UIN Sunan Ampel Surabaya, the most online learning method used was discussion, synchronous or asynchronous as 90, $2 \%$ (Jariyah \& Tyastirin, 2020). However, especially for Science learning students was also need experience in activities of lab work to get better concept understanding such as in the concept of energy transform matter. The lab work activities need to be done to further deepen concept understanding for students. The lab work is one way to acquire concept understanding through the development of science process skills, training thinking skills and scientific attitudes. In the activities of lab work there are the process whereby students trained to identify, determine, change and control variables. The concept of energy in life particularly regarding the conversion of energy and energy conservation. This material need lab work because of its characteristics which is abstract and applicable.

Lab work in learning activities during the pandemic is in trouble due online learning. Challenge for online learning in energy matter is how to provide lab work experience for students using virtual laboratory. Based on it, alternative solutions are needed to be conducted in the lab work online learning activities. One of the relevant solution is the use of Physics Education Technology (PhET) simulation as a medium for lab work alternative activities in learning. A developed and tested carefully of education simulation can be effectively interest and encourage exploration of productive authentic scientific phenomenon, and also provide credible model animation to guide the students thinking processes (Wieman et al., 2008).

PhET is one of interactive computer simulation developed by the University of Colorado Boulder. PhET provides simulations with a wide variety of topics and the application of real relevant concept in physics, chemical, biology, and also mathematics. $\mathrm{PhET}$ gives an experience of virtual laboratory activities. One the use of virtual laboratory of $\mathrm{PhET}$ is to make delivery concept of matter and mastery of Physics abstracting matter become easier (Saregar, 2016). There are various PhET simulation on science and math lessons that can be accessed for free. PhET itself is user friendly because it can be used online or offline .When used in offline mode, it is required to install flash plug-in and java program first, then download the PhET simulation on the site. Thus, it can alleviating the needs of cost or quotas.

Based on a number of the results of the study before, the use of PhET simulation in students learning experiences had an impact in their concept understanding. The results of research conducted by Najib (2015) showed an increase of students understanding who uses PhET simulation. In addition, the result of the study conducted by Saregar (2016) is also showed the increase of concept understanding in Physics matter after experienced with PhET simulation in their learning activities. The use of PhET simulation in learning activity is effective to increase students concept understanding in solar system matter significantly (Prima et al., 2018). 
Furthermore, in this covid-19 pandemic the use of virtual laboratory is necessary to substitute real laboratory work to enhance students' experience and students' understanding. As we know that learning activity in laboratory is facing challenge during this pandemic. Globally, about hundreds of laboratory practical session in academia for 2020/2021 have been suspended without any clear indication (Vasiliadou, 2020). The only way to deliver laboratory work based learning in this Covid-19 is using virtual laboratory (Sugiharti \& Sugandi, 2020). Moreover, network problem associated with signal and data package quotas become the most encumbering aspect of online learning in Covid-19 pandemic (Sinaga \& Harahap, 2020), especially in UIN Sunan Ampel Surabaya (Rachmawati et al., 2020). Thus, PhET ability to be operated both online and offline help student to overcome this problem associated with signal and data package quotas.

Based on the description above, it is expected that the use of PhET simulation in pandemic can be a solution media for lab work based learning. Thus, the purpose of this research is to describe the effectiveness of PhET Simulation as a solution media for lab work learning during pandemic.

\section{METHOD}

\section{Research Design}

This research is pre-experimental research using one group pretest-posttest design. The experiment design can be seen below:

$$
O_{1} \quad X
$$

where; $\mathrm{O}_{1}$ : pre-test; $\mathrm{O}_{2}$ : post-test; $\mathrm{X}$ : treatment, which is learning using PhET simulation

\section{Population and Sample}

The population in this research were students of Science Education study program from Tarbiyah and Lecturer Training Faculty of UIN Sunan Ampel Surabaya who programed the Energy in Life for the 2020/2021 academic year. There were 30 students as sample that was chosen by saturated sampling technique.

\section{Data Collection Techniques and Instrument Development}

The instrument which is developed was students' understanding concept test sheet and students' responses questionnaire using Google-form. Student's concept understanding test sheet is used to obtain data for student's concept understanding. This instrument is consist of 15 essay questions with four cognitive domain begin from understanding (C2) level to analyzing (C4). Measurement of students' understanding concept test sheet is using Aiken's $\mathrm{V}$ formula to find content validity coefficient (Hendryadi, 2017). The item supposed to be valid if the value of content validity coefficient is more than 0.78 (Akhtar, 2017). The formula of Aiken's $\mathrm{V}$ is given below:

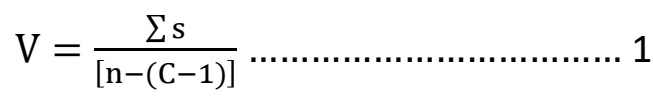

where;

$\mathrm{V}$ : content validity coefficient

s $\quad: \mathrm{R}-\mathrm{L}_{0}$

$\mathrm{N}$ : number of expert

$\mathrm{R}$ : value given by expert

$\mathrm{L}_{0} \quad$ : lowest assessment value (1)

$\mathrm{C}$ : highest assessment value (4)

The instrument's validity and reliability of student's understanding concept test sheet shown in Table 1. 
Table 1. Validity and reliability of student's understanding concept test sheet

\begin{tabular}{cccc}
\hline Validity & Number & Content validity coefficient $(\mathbf{V})$ & criteria \\
\hline 1 & 0.89 & valid \\
2 & 0.89 & valid \\
3 & 0.89 & valid \\
4 & 0.89 & valid \\
5 & 0.89 & valid \\
6 & 0.89 & valid \\
7 & 1.00 & valid \\
8 & 0.89 & valid \\
9 & 0.94 & valid \\
10 & 0.89 & valid \\
11 & 0.89 & valid \\
12 & 0.94 & valid \\
13 & 1.00 & valid \\
14 & 1.00 & valid \\
15 & 1.00 & valid \\
\hline Reliability & Value & Criteria \\
\hline & & 0,908 & high \\
\hline
\end{tabular}

The instrument's validity and reliability of student's response questionnaire shown in Table 2.

Table 2. Instrument test of questionnaire

\begin{tabular}{|c|c|c|c|c|}
\hline Validity & Number & Correlation & r table & criteria \\
\hline & 1 & 0,658 & \multirow{9}{*}{0,361} & valid \\
\hline & 2 & 0,770 & & valid \\
\hline & 3 & 0,736 & & valid \\
\hline & 4 & 0,784 & & valid \\
\hline & 5 & 0,703 & & valid \\
\hline & 6 & 0,806 & & valid \\
\hline & 7 & 0,817 & & valid \\
\hline & 8 & 0,734 & & valid \\
\hline & 9 & 0,865 & & valid \\
\hline \multirow[t]{2}{*}{ Reliability } & & r alpha & r table & criteria \\
\hline & & 0,826 & 0,361 & Reliabel \\
\hline
\end{tabular}

Students' responses questionnaire is consist of 9 questions using Likert scale which then analyzed quantitively. This questionnaire proposes to find out student's responses related to the integration of PhET simulation during their learning activity to increase their concept understanding especially in energy topic. Also, the questions explore about their responses to the lecture's activities during learning process.

\section{Data Analysis Techniques}

The effectiveness analysis of PhET Simulation that is integrated in distance learning was done by analyzing students' pretest and post-test scores using: (a) paired-sample t-test (Gibbons \& Chakraborti, 2011); (b) calculating n-gain average by formula: n-gain= (post-test score - pretest score)/(maximum score - pretest score) $\times 100$, with category: (1) high if n-gain $>70$; (2) moderate if $30 \leq n$-gain $\leq 70$; and (3) low if n-gain < 30 (Archambault, 2008); and (c) calculating student's responses to the integration of PhET Simulation in distance learning. Student's responses are said good if the mean percentage of student response score for each component is $\geq 75 \%$ (Astutik \& Prahani, 2018). Student's response are analyzed by 
quantitative and qualitative descriptive using criteria of: (1) very positive if responses $\geq 75 \%$; (2) positive if $50 \% \leq$ responses $<75 \%$; (3) less positive if $25 \% \leq$ responses $<50 \%$; and (4) Not positive if responses $<25 \%$ (Astutik \& Prahani, 2018).

\section{RESULTS AND DISCUSSION}

\section{Concept Understanding in Energy Topic assisted with lab work activity using PhET Simulation}

Concept understanding test is consist of 15 essay questions relate to $\mathrm{PhET}$ simulation in energy conversion, energy conservation, kinetic energy, and potential energy topics. The questions are constructed based on revised Bloom's cognitive taxonomy categorization from $\mathrm{C} 2$ to $\mathrm{C} 4$ level. They are; understanding, applying, and analyzing.

In cognitive level of understanding (C2), students are asked to identify variables in configuration of energy components during the PhET simulation, either configuration provided by lecturer or configuration they construct by themselves. In this case, some students still confused in identifying the independent, dependent and control variables of the energy conversion simulation. However, almost all of the students still remember more about the types of energy and its conversion which is learned in the previous stages.

Students are also asked to arrange the meaning of instructional messages, both figures or script. Students are directed to inferring and explaining the data from graph that is obtained from simulation. In this case, students use this simulation interactively to find, explain, and give reason to important concept of energy such as finding relation and causal. Students are considered to understand when they are able to construct a relation between novel knowledge and prior knowledge. In other words, concept is a building of scheme constituent. To comprehend the new knowledge meaningfully, students have to independently and correctly able to make connections between previous information and new information then applying concepts into the current situations (Inayah et al., 2020). Some students face difficulties in this questions because they aren't accustomed to give reason and explain about scientific phenomenon in the daily life and related it to the scientific law and formula, such as the law of energy conservation.

In cognitive level of applying (C3), students are asked to execute the procedure as guided before to be applied on different way in manipulating variables and conclude the result. This level trains students' skills and algorithm with minimum two criterion such as, doing procedure in fixed order and when the procedure is followed correctly then the final result is the answer that can be determined before. In this level, the dominant activities was practicing. Practice is necessary to master any skill; students must have the opportunity to practice the knowledge and skills that will be evaluated (Limbach \& Waugh, 2010).

In cognitive level of analyzing (C4), students are asked to break up material into constituent parts and determine how parts be related with each other. In this step, organizing process occurs where students build systematic and coherent relation between pieces of information provided. For example, through PhET simulation students are asked to explain relation between the position of skater, the mass of skater, friction, and energy. In this case, they organize, find relation between one part to another. Thus, the multiple concept representation for example skater's motion and graph can be related clearly. Besides, analyzing question type is one of the indicator in measuring higher order thinking skills which is very important to develop in this era of $21^{\text {st }}$ century learning.

Before t-test is conducted, normality test as pre-analyzed test was done using SPSS 26. The result are 0.141 and it is greater than 0.05 . Thus, it can be concluded that the sample is normally distributed. The differentiation between students concept understanding before and after treatment is tested using paired sample t-test. The result shown in Table 3. 
Table 3. Paired-sample t-test of pretest-postest

\begin{tabular}{|c|c|c|c|c|c|c|c|c|}
\hline & \multicolumn{5}{|c|}{ Paired Differences } & \multirow[t]{3}{*}{$t$} & \multirow[t]{3}{*}{$d f$} & \multirow[t]{3}{*}{ Sig. (2-tailed) } \\
\hline & \multirow[t]{2}{*}{ Mean } & \multirow[t]{2}{*}{$\begin{array}{l}\text { Std. } \\
\text { Dev }\end{array}$} & \multirow[t]{2}{*}{$\begin{array}{l}\text { Std. Error } \\
\text { Mean }\end{array}$} & \multicolumn{2}{|c|}{$\begin{array}{l}95 \% \text { Confidence Interval } \\
\text { of the Difference }\end{array}$} & & & \\
\hline & & & & Lower & Upper & & & \\
\hline Pretest-postest & -43.73 & 16.79 & 3.06 & -50.00 & -37.46 & -14.26 & 29 & .000 \\
\hline
\end{tabular}

Based on the Table 3, it is shown that the value of significance is 0.00 that is less than 0.05. Thus, it can be concluded that there is significant differentiation between students concept understanding before and after learning in energy topic using PhET simulation. It also points that learning activity with lab work using PhET simulation enhances students comprehension. It was because as an interactive multimedia, PhET change an abstract concept into concrete terms which can help them to understand the concept better. The visualization enables student to interact, respond and communicate, so information can be more durable and easy to remember (Supurwoko et al., 2017). This is in line with the theory of double encoding (dual code theory) certifying that a person remember better any information when it is given not only verbally but also visually. Based on the survey, the result showed that more than 75 percent of students said they agreed that PhET help them in concept learning, enhance thinking skills, build confidence, develop independence, and improve their test scores (Bandoy et al., 2015). Research about learning showed that students learn better when they build their own understanding of scientific ideas in their existing knowledge framework. In PhET simulation, visual display and direct interaction can develop students understanding related to daily scientific phenomenon (Wieman et al., 2008).

Pretest and post-test score from sample then analyzed using percentage of average normalized gain $(N$-Gain). The result showed that the average $\mathrm{N}$-gain is 0.63 which is interpreted as medium level. The instructional results are said to be effective if the N-Gain score is greater than 0,3 (Ramlawati et al., 2014); (Colt et al., 2011). The statistical description of N-Gain and distribution of score for each test number shown in Table 4 and Figure 1 respectively.

Table 4. Statistical description of pretest-posttest and N-Gain

\begin{tabular}{cccc}
\hline & Pretest & Posttest & N-Gain \\
\hline Total of Data & 30 & 30 & 30 \\
Mean & 31.03 & 74.77 & 0.63 \\
Standard Deviation & 19.554 & 10.054 & \\
The Lowest Score & 4 & 47 & 0 \\
The Highest Score & 75 & 93 & 1 \\
\hline
\end{tabular}

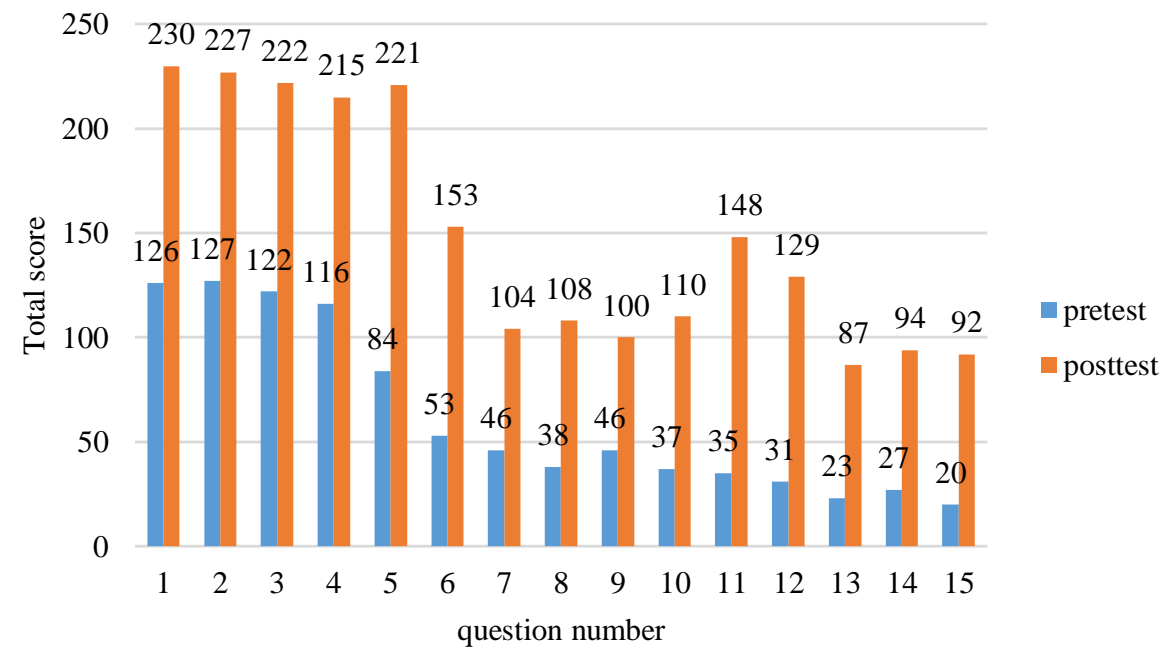

Figure 1. Distribution of pretest-postest score 
Thus, there is increasing students understanding after attending learning using PhET simulation. Most sample reach medium category though some reached high category. This can occur due to every student different in terms of factors that affect the understanding of them such as the level of intelligence that genetically determined, motivation, the experience of learning, learning environment, and so on. This is compounded that learning done online different to learning face-to-face in knowledge transfer process. Online learning although recognized benefits from the flexibility, place, time , and the learning tends to be relaxed. But it has several weaknesses such as limited signals of the data, time, and access of two way interaction so as to allow misunderstanding for even misconception. This is heightened learning environment for each student at homes different from one another and did not always conducive for learning. On the other hand, learning flexibility is a challenges for students to fight their laziness as well as demanding honesty and self discipline (Farida et al., 2020).

Learning by using PhET simulation can be done independently because $\mathrm{PhET}$ is designed as an interactive medium that allows independent exploration by students. However, the role of good learning instructional and portion of guidance from lecturer is very determined. In pandemic covid-19 situation when learning and discussion done online through G-Meet and WAG with all case, allow lack of well information absorption although it can be played or viewed repeatedly. This is because gesture of lecturer in learning having power who directs students to understand the topics better. Representative gesture can increase students understanding through mental simulation, action, and perception.

Learning activity using PhET simulation is guided using tutorial video to deliver learning topic and to introduce the features of PhET simulation in energy conservation sub topic. This tutorial video is distributed using online learning platform WhatApp Group (WAG) as can be seen in Figure 2. The introduction of PhET simulation feature is done after lecturer delivers the concept related to the topic of energy conservation. The worksheet are available and provided by lecturer to facilitate student in exploring these features of PhET simulation. On the other hand, this worksheet help lecturer to guide student in order to make the exploration become more directed and measurable. Online discussion is also held to analyze and answer the worksheet questions, where these questions only can be answered by students after trying PhET simulation first.

\section{Systems Screen}

Build your own system, with energy sources, changers, and users. Track and visualize how energy flows and changes through your system.

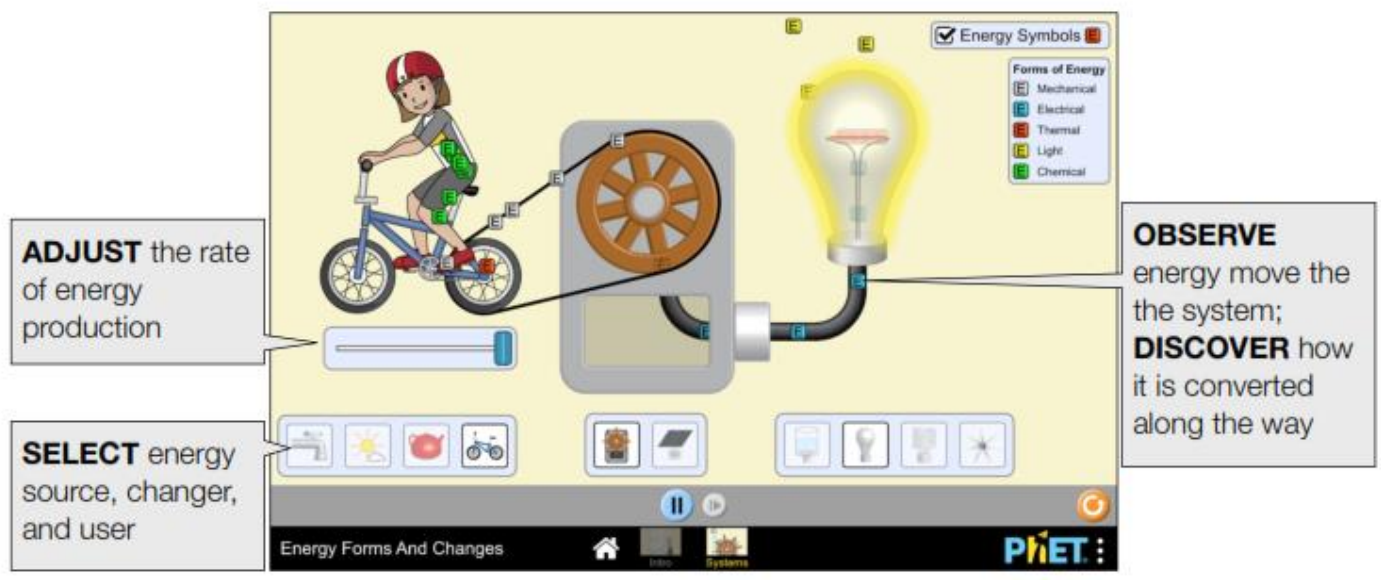

Figure 2. Guidance and introduction to PHET simulation features in energy conservation topic (Energy forms and transformation) 
The worksheet is constructed with some entry column that provided to accommodate student's answers. It consist of (1) configuration of energy components (2) variables identification; and (3)energy transformation. In configuration of energy component column there arefour configuration of different component that must be simulated by students. Thus, the variables can be different in every number depend on the configuration. Then, it can be identified in the second column. Lab work as a scientific activity contains a process where students are trained to identify, determine, manipulate, and control variables. In the third column, students were asked to describe and conclude the process of energy transformation.

Students understand the concept better when they get chance to make a direct interaction by simulating rather than just watching. Most of learning process occurs when students have question that lead them to make an exploration through simulation and bring an invention to answer that question. When students get involved in independent exploration, they learn better. Thus, PhET simulation can be designed to increase the topic complexity in order to make it effective and interesting to prepare student in the real scientific research (Wieman et al., 2008).

Worksheet is consist of 10 questions and 5 among them are provided with configuration. Students only asked to make a simulation based on the configuration provided. For the next question numbers, students are asked to create another configuration based on their creativity but they have to consider the compatibility of the components. In the same time, they are asked to determine variables and the transformation of energy. For next question numbers, students are asked to make an analysis and explanation about base concept related to the simulation.

Based on the implementation result, it can be seen that students can discuss well in the online group discussions. They also completed the worksheet well. This is related to the balance role from the lecturer as a learning facilitator and students empowerment through real experience using tools and science practices. Thus, it can support learning activity effectively (Atabas et al., 2020). The role of lecturer as stated in constructive theory is helping students to construct their knowledge. Bruner noted that lecturer can improve students understanding by giving scaffolding until students become independent learner to achieve their goal (Arends, 2012). Thus, online learning for some topic material where lab work is necessary to strengthen the concept understanding can be done effectively and become meaningful learning through the implementation of PhET simulation with supporting discussion and worksheet.

\section{Response to the implementation of PhET simulation in learning with lab work activity}

The questionnaire was distributed to students to obtain their responses to learning with lab work activity using $\mathrm{PhET}$ simulation. The questions in the questionnaire were constructed to explore students responses about aspects of using PhET, those are 1) interesting and boost curiosity; 2) represent virtual lab work; 3) easy to use with assist of worksheet; 4) enhance understanding; 5) train thinking skills (critical and creativity). Besides, the questionnaire also explore student's responses relate to lecture activities during learning process. The percentage of each aspect can be seen in Table 5.

Table 5. the percentage of student responses about PhEt simulation

\begin{tabular}{lllllll}
\hline No & \multicolumn{1}{c}{ Indicators } & \multicolumn{5}{c}{ Scale's percentage (\%) } \\
\cline { 3 - 7 } & & $\mathbf{1}$ & $\mathbf{2}$ & $\mathbf{3}$ & $\mathbf{4}$ & \multicolumn{1}{c}{$\mathbf{5}$} \\
\hline 1 & Phet is interesting and boost curiousity & 0 & 0 & 3.3 & 50 & 46.7 \\
2 & Phet represents virtual practical learning & 0 & 0 & 3.3 & 36.7 & 60 \\
3 & Phet is easily practiced assisting by worksheet & 0 & 0 & 10 & 43.3 & 46.7 \\
4 & Phet enhances concept understanding & 0 & 0 & 10 & 40 & 50 \\
5 & Phet trains thinking skills (critical and creative) & 0 & 0 & 10 & 43.3 & 46.7 \\
6 & Lecturer fascilitates online pretest-postest & 0 & 0 & 3.3 & 26.7 & 70 \\
7 & Lecturer fascilitates tutorial video to introduce Phet sims & 0 & 0 & 3.3 & 23.3 & 73.3 \\
& relates to energy topic & & & & & \\
\hline
\end{tabular}




\begin{tabular}{lllllll}
\hline No & \multicolumn{1}{c}{ Indicators } & \multicolumn{5}{c}{ Scale's percentage (\%) } \\
\cline { 3 - 7 } & \multicolumn{1}{c}{$\mathbf{1}$} & $\mathbf{2}$ & $\mathbf{3}$ & $\mathbf{4}$ & $\mathbf{5}$ \\
\hline 8 & $\begin{array}{l}\text { Lecturer fascilitates online group discussion to do the } \\
\text { worksheet }\end{array}$ & 0 & 0 & 3.3 & 16.7 & 80 \\
9 & $\begin{array}{l}\text { Lecturer gives feedback to the discussion result and } \\
\text { worksheet }\end{array}$ & 0 & 0 & 6.7 & 26.7 & 66.7 \\
\hline
\end{tabular}

In the aspect of PhET capability to interest and boost curiosity, students gave positif response about $96,7 \%$. It means simulations using PhET is able to make students actively engaged in learning caused their self-interest to an interactive media and features. Several characteristics of $\mathrm{PhET}$ which makes it attractive among them were visually dynamic environment which can be controlled directly by the user, the challenge that not too hard or too easy, as well as the visual complexity sufficient to create curiosity (Wieman et al., 2008). The PhET simulation providing dynamic access for multiple representation, make that is invisible become visible, facilitate inquiry, and allow quick access to some trial as well as exciting times and it is fun for lecturers and students especially millenial generation today.

In the aspect of PhET capability to represent virtual lab, the obtained positive response percentage is $96,7 \%$. It means learning activity with lab work using PhET simulation is a solution to lab work virtual activity especially during pandemic that is impossible to do with real laboratory kit. It is as revealed by Wieman et al. (2010) that PhET simulation can help lecturer to introduce new topic, build concept and skill, strengthen scientific ideas, and carry out learning reflection. In addition, PhET simulation allows explorations that does not allow in lab work using real laboratory equipment. In this case, students can explore energy conservation using various variables such as shape of track, starting height and skater's velocity, skater's mass, and friction. Students can repeat their experiment rapidly and see the effect from various parameter changing. This can increase understanding process. So, this simulation would be able to bring out the questions of "how if .." and its answers from students. From this point, their thinking ability is developed.

In the aspect of PhET simulation is easy to use assisted with worksheet, the percentage is $90 \%$. This may due to the coaching process from lecturer by online does not reach optimum level, some students maybe has the limited signal and lost their connection in the middle of the coaching process. However, student worksheet is constructed to increase students understanding and develop their thinking skills. PhET simulation is a well constructed media that enriched learning curricula which can not stand alone. PhET should be part of a whole instructional design, it needs lecturer guidance in a proper portion and good manual such as students worksheet (Wieman et al., 2010).

In the aspect of PhET enhances understanding, the percentage reach $90 \%$. This may be due to some of the students were still difficult to interpret and analyze data from the simulation exercise that still need to be repeated and familiarized. Because not all learning activities in other subjects and lectures designed to facilitates the process of a deep understanding, real experiences, and sharpening analysis skill. PhET is a media to represent a scientific model in learning, but is still much thought necessary for students to understand the concept contained in that simulation. If only just operating the simulation, all students may be able to do that, but to understand the concept behind that simulation, complex thinking process would necessary. However, PhET simulation provides opportunity for students to repeat their experiment and extend it to clarify and strengthen their understanding.

In the aspect of PhET trains thinking skills, the percentage is $90 \%$. it shows that students get the opportunity and experience to think in various way, such as "how if $i$ choose this or that" and so on. Worksheet as manual is necessary to guide students and strengthen their understanding, but the portion of guidance is also considered to meet proper demand of their thinking skill developing process. Too structured and explicit worksheet may provide less opportunity for student to be creative. Otherwise, open minded worksheet provides student creativity. The point is, how to engage students in a productive independent 
exploration. It is confirmed in other research that the implementation of CCL model integrated with PhET simulation was proven to be a practical and effective way to increase junior high schools students scientific creativity (Astutik \& Prahani, 2018).

While for questions 6-9 represents lecturer's activities include fascilitates pretestpostest, tutorial video to introduce phet sims, online group discussion to do woksheet, and feedback of the results. All the positive response reach over than $90 \%$. It means that lecturer had implemented the instructional to support PhET virtual laboratory practices as well.

Generally, based on Figure 3, the average positive percentage is over than $90 \%$. So, it can be stated that students responses to PhET simulation implementation in learning process is very positive. It is because this PhET simulation is interesting and boost students curiosity. It also represents virtual lab work and easy to use with the assist of students worksheet. Thus, it can help students to understand the concept and develop their thinking skills. This is in line with the aim of using PhET simulation according to Saregar (2016) in which the use of this virtual laboratory is making the delivery and mastery of the concept of Physics matter especially of an abstract topic become easier.

\section{CONCLUSION}

Based on the result and discussion above, it can be concluded that most of the students can join learning activity using PhET simulation in energy topic well with the assist of student worksheet. PhET simulation enhances students understanding with $\mathrm{N}$-gain average of 0.63 (medium). Students responses are also very positive. Generally, this PhET simulation is effective to use as a solution media for lab work during pandemic to enhance students understanding.

\section{RECOMMENDATION}

Learning activity using PhET simulation can be done independently. To increase the effectiveness of PhET simulation as learning media in Covid-19 pandemic era, the role of good learning instructional and proper portion of lecturer guidance is very necessary.

\section{ACKNOWLEDGMENT}

We thank our RISTEKDIKTI for the support the research found. The Chairman of co-author for the writing and research guidance. In addition, and I thank to the lectures of Mataram University for the support in research.

\section{REFERENCES}

Anderson, L.W., Krathwohl, DR.,Airasian., P.W., Cruikshank, K.A., Mayer, R.E., Pintrich., P.R., Raths, J., \&Wittrock, M.C. (2001). A taxonomy for learning, teaching and assesing: A revision of Bloom Taxonomy of educational objectives, a bridged edition. New York: Longman.

Akhtar, H. (2017, September). Berapa Jumlah Rater dan Nilai Minimal yang Dapat Diterima pada Uji Validitas Isi? Semesta Psikometrika. Berapa Jumlah Rater dan Nilai Minimal yang Dapat Diterima pada Uji Validitas Isi?

Arends, R. (2012). Learning to teach (9th ed). McGraw-Hill.

Astutik, S., \& Prahani, B. K. (2018). The Practicality and Effectiveness of Collaborative Creativity Learning (CCL) Model by Using PhET Simulation to Increase Students' Scientific Creativity. International Journal of Instruction, 11(4), 409-424. https://doi.org/10.12973/iji.2018.11426a

Atabas, S., Schellinger, J., Whitacre, I., Findley, K., \& Hensberry, K. (2020). A tale of two sets of norms: Comparing opportunities for student agency in mathematics lessons with and without interactive simulations. The Journal of Mathematical Behavior, 58, 100761. https://doi.org/10.1016/j.jmathb.2020.100761

Bandoy, J. V. B., Pulido, M. T. R., \& Sauquillo, D. J. (2015). The Effectiveness of using PHET Simulations for Physics Classes: A Survey. 4. 
Colt, H. G., Davoudi, M., Murgu, S., \& Zamanian Rohani, N. (2011). Measuring learning gain during a one-day introductory bronchoscopy course. Surgical Endoscopy, 25(1), 207-216. https://doi.org/10.1007/s00464-010-1161-4

Farida, I., Sunarya, R. R., Aisyah, R., \& Helsy, I. (2020). Pembelajaran Kimia Sistem Daring di Masa Pandemi Covid-19 Bagi Generasi Z. 11.

Hendryadi. (2017). Validitas Isi: Tahap Awal Pengembangan Kuesioner. Vol.2 No.2. https://doi.org/10.36226/jrmb.v2i2.47

Inayah, N., Hidayat, M. T., \& Nur, M. (2020). Effectivity of Scientific Approach Oriented Learning in Heredity toward Senior High School Students's Scientific Creativity. JPPS (Jurnal Penelitian Pendidikan Sains), 10(1), 1857. https://doi.org/10.26740/jpps.v10n1.p1857-1873

Jariyah, I. A., \& Tyastirin, E. (2020). Proses dan Kendala Pembelajaran Biologi di Masa Pandemi Covid-19: Analisis Respon Mahasiswa. Jurnal Penelitian Dan Pengkajian Ilmu Pendidikan: E-Saintika, 4(2), 183. https://doi.org/10.36312/e-saintika.v4i2.224

Limbach, B., \& Waugh, W. (2010). Developing higher level thinking. 9. https://files.eric.ed.gov/fulltext/EJ1097083

Prima, E. C., Putri, A. R., \& Rustaman, N. (2018). Learning solar system using PhET simulation to improve students' understanding and motivation. Journal of Science Learning, 1(2), 60. https://doi.org/10.17509/jsl.v1i2.10239

Rachmawati, Y., Ma'arif, M., Fadhillah, N., Inayah, N., Ummah, K., Siregar, M. N. F., Amalyaningsih, R., Aftannailah, F., \& Auliyah, A. (2020). Studi Eksplorasi Pembelajaran Pendidikan IPA Saat Masa Pandemi COVID-19 Di UIN Sunan Ampel Surabaya. Vol.1 No.1. https://doi.org/10.15642/ijsl.v1i1.633

Ramlawati, R., Liliasari, L., Martoprawiro, M. A., \& Wulan, A. R. (2014). The Effect of Electronic Portfolio Assessment Model to Increase of Students' Generic Science Skills in Practical Inorganic Chemistry. Journal of Education and Learning (EduLearn), 8(3), 179-186. https://doi.org/10.11591/edulearn.v8i3.260

Saregar, A. (2016). Pembelajaran Pengantar Fisika Kuantum dengan Memanfaatkan Media Phet Simulation dan LKM Melalui Pendekatan Saintifik: Dampak pada Minat dan Penguasaan Konsep Mahasiswa. Jurnal Ilmiah Pendidikan Fisika Al-Biruni, 5(1), 53. https://doi.org/10.24042/jpifalbiruni.v5i1.105

Sinaga, L., \& Harahap, K. R. P. (2020). Analisis Strategi Pembelajaran Jarak Jauh pada Materi IPA Selama Pandemi Covid-19 di Kota Medan. Vol.1 No.1. Retrieved from https://jurnal.unimed.ac.id/2012/index.php/JPPIPAI/article/view/19433

Sugiharti, S., \& Sugandi, M. K. (2020). Laboratorium Virtual: Media Praktikum Online untuk Meningkatkan Pemahaman SIswa di Masa Pandemi. Prosiding Seminar Nasional Pendidikan, Vol.2, 45-51. Retrieved from https://prosiding.unma.ac.id/index.php/semnasfkip/article/view/299

Supurwoko, S., Cari, C., Sarwanto, S., Sukarmin, S., \& Suparmi, S. (2017). The effect of Phet Simulation media for physics lecturer candidate understanding on photoelectric effect concept. International Journal of Science and Applied Science: Conference Series, 1(1), 33. https://doi.org/10.20961/ijsascs.v1i1.5108

Vasiliadou, R. (2020). Virtual laboratories during coronavirus ( COVID -19) pandemic. Biochemistry and Molecular Biology Education, 48(5), 482-483. https://doi.org/10.1002/bmb.21407

Wieman, C. E., Adams, W. K., Loeblein, P., \& Perkins, K. K. (2010). Teaching Physics Using PhET Simulations. The Physics Lecturer, 48(4), 225-227. https://doi.org/10.1119/1.3361987

Wieman, C. E., Adams, W. K., \& Perkins, K. K. (2008). PHYSICS: PhET: Simulations That Enhance Learning. Science, 322(5902), 682-683. https://doi.org/10.1126/science.1161948 